to ultrastructural evidence of cytopathic change in these large lymphoid cells.

Other workers using immunoperoxidase stains on paraffin-embedded sections of H.D. lymph-nodes have demonstrated intracellular immunoglobulin in "atypical reticulum cells", $, 7,7$ morphologically and immunologically similar to the large lymphoid cells seen in peripheral blood. In paraffin-embedded hæmatoxylin and eosin-stained sections of lymph-node from this patient these cells sometimes seemed to be in lacuna, which may have resulted from proportionally greater shrinkage of œdematous large cells during processing. Perhaps therefore the so-called lacunar cell is a processing artefact and not a true histological feature.

Similar large lymphoid cells have been seen in conditions of known antigenic challenge-infections, after immunisation, rheumatoid arthritis and systemic lupus erythematosus. ${ }^{1,5}$ I believe the large lymphoid cells in the peripheral blood of patients with H.D. are B lymphocyte casualties in a "lymphocyte civil war", 8 and that they are not necessarily malignant.

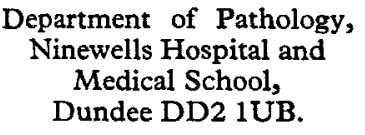

James A. Dunbar.

\section{SURFACE CHARACTERISTICS OF HODGKIN'S LYMPHOMA CELIS}

SIR,-Braylan et al. ${ }^{9}$ reported the surface characteristics of a " presumably neoplastic large cell of Hodgkin's disease". We recently observed by scanning electron microscopy cells similar to the cell illustrated.

A 26-year-old male had a diagnosis of nodular sclerosis Hodgkin's disease established by cervical lymph-node biopsy. Staging coeliotomy was carried out, and the spleen was found to contain multiple nodules of Hodgkin's disease from which cells were separated for scanning electron microscopy.

Light microscopic examination of the splenic infiltrate again showed nodular sclerosis Hodgkin's disease. The cellular infiltrate consisted mainly of lymphocytes but also included some eosinophils, malignant-looking histiocytes (reticulum cells), and Reed-Sternberg cells, many of these last having characteristics of "lucunar cells".

For scanning electron microscopy, cells were fixed in $1.5 \%$ gluteraldehyde, postfixed in $1 \%$ osmium tetroxide, dehydrated in increasing concentrations of alcohol which was followed by amyl acetate, and prepared by the critical-point drying method.

The majority of cells seen by scanning electron microscopy were lymphocytes either with smooth surfaces or with varying numbers of villous processes. Occasionally, a cell several times the size of the lymphocytes was observed (see accompanying figure). These large cells were covered with many stubby villous processes and were surrounded by lymphocytes. The majority of these lymphocytes were smooth or had few villous structures and had the appearance of $T$ cells. ${ }^{10}$

The large cell in this case seems similar to the large cell demonstrated by Braylan et al. ${ }^{9}$ except that it appeared to have a greater number of villi which were somewhat shorter and not as slender.

We have not observed similar cells of this size isolated from spleens and lymph-nodes with other types of lymphomas or reactive processes. Therefore, we feel that the large cells correspond to the large cells seen in the histological section-namely, the mononuclear malignant histiocyte, the Reed-Sternberg cell or its variant, the lacunar cell.

6. Garvin, A. J., Spicer, S. S., Parmley, R. T., Munster, A. M. F. exp. Med. 1974, 139, 1077.

7. Taylor, C. R. Lancet, 1974, ii, 802.

8. De Vita, V. New Engl. F. Med. 1973, 289, 801

9. Braylan, R. C., Jaffe, E. S., Berard, C. W. Lancet, 1974, ii, 1328.

10. Pollick, A., Lampen, N., Clarkson, B. D., DeHarven, E., Bentwich, Z., Siegal, F. P., Kunkel, H. G. F. exp. Med. 1973, 138, 607.

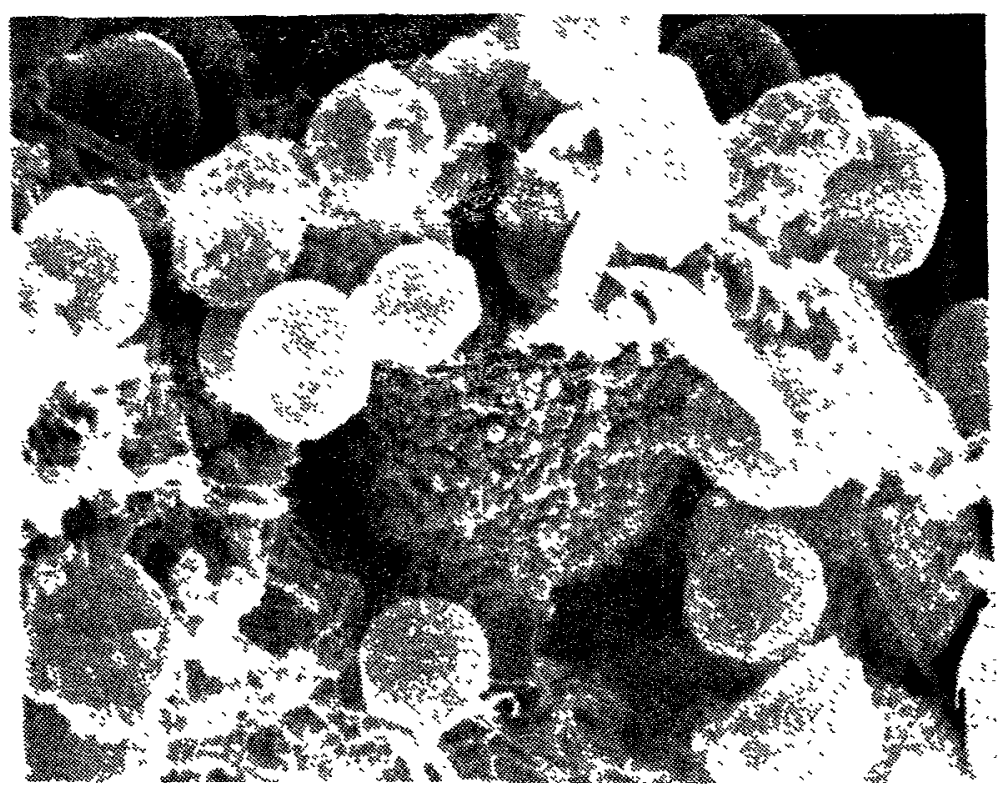

Large cell covered with stubby villous processes and surrounded by lymphocytes, most of which have smooth surfaces.

We are unable to comment on the origin of the large cell on the basis of its surface morphology.

Department of Pathology,

University of Michigan,

Ann Arbor, Michigan 48104, U.S.A.

B. SCHNITZER

M. L. MEAD.

\section{HODGKIN'S DISEASE IN PHYSICIANS}

SiR,-After much hesitation, I have been encouraged by my colleagues to provide an addendum to the article by Dr Vianna and his associates (July 20, p. 131) supporting the possibility that direct or indirect contact with Hodgkin's patients may be an important consideration for medical personnel as a high-risk group. One of my former associates worked with intralymphocyte proteins, ${ }^{1,2}$ a project which required harvesting pure lymphocytes from large amounts of tumour removed either at operation or at necropsy. Since only absolutely pure lymphocyte suspensions were appropriate for the investigations, very careful cleansing, washing, and centrifugation of the malignant cells was essential. Although disposable latex gloves were worn during these mancuvres, this precaution was not always followed. Some two years later after completing this work and assuming a position at another medical centre, this physician developed Hodgkin's disease, which took an extremely fulminant course and remained uncontrolled despite treatment.

There can be no certainty that an isolated incident is evidence for the transmissibility of Hodgkin's disease. Yet epidemiological data outlined by Dr Vianna and others, as well as other contemporary reviews, make an oncogenic infectious agent suspect. This letter is written to alert investigators that caution should be exercised in laboratories where neoplastic tissues are handled constantly.

Graduate Hospital,

Philadelphia,

Pennsylvania 19146, U.S.A. JEROME I. BRODY.

\section{OBESITY AND CORONARY HEART-DISEASE}

SIR,-Dr Dock (Jan. 4, p. 41) is correct in stating that relative weight is by no means the same kettle of fish in Japan and Australia. The middle-aged Japanese male, $170 \mathrm{~cm}$. in height, weighing $60 \mathrm{~kg}$., would on Australian standards be at the 5 th percentile of relative body-weight.

1. Mobarak, M. A., Brody, J. I. Clinica chim. Acta, 1970, 3, 609

2. Mobarak, M. A., Brody, J. I. ibid. p. 635 . 